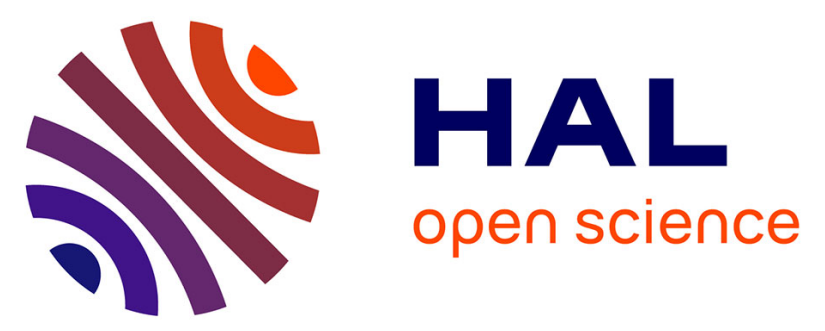

\title{
Radiometric dates for the Middle Palaeolithic sequence of Payre (Ardèche, France)
}

Hélène Valladas, N. Mercier, L.K Ayliffe, Christophe Falguères, Jean-Jacques Bahain, J.-M. Dolo, L. Froget, J.-L. Joron, H. Masaoudi, J.-L. Reyss, et al.

\section{- To cite this version:}

Hélène Valladas, N. Mercier, L.K Ayliffe, Christophe Falguères, Jean-Jacques Bahain, et al.. Radiometric dates for the Middle Palaeolithic sequence of Payre (Ardèche, France). Quaternary Geochronology, 2008, 3, pp.377-389. 10.1016/j.quageo.2008.01.001 . halshs-00347697

\section{HAL Id: halshs-00347697 https://shs.hal.science/halshs-00347697}

Submitted on 2 May 2019

HAL is a multi-disciplinary open access archive for the deposit and dissemination of scientific research documents, whether they are published or not. The documents may come from teaching and research institutions in France or abroad, or from public or private research centers.
L'archive ouverte pluridisciplinaire HAL, est destinée au dépôt et à la diffusion de documents scientifiques de niveau recherche, publiés ou non, émanant des établissements d'enseignement et de recherche français ou étrangers, des laboratoires publics ou privés. 


\title{
Radiometric dates for the Middle Palaeolithic sequence of Payre (Ardèche, France)
}

\author{
H.Valladas ${ }^{\mathrm{a}}$, N.Mercier ${ }^{\mathrm{a}}$, L.K.Ayliffe ${ }^{\mathrm{b}}$, C.Falguères ${ }^{\mathrm{c}}$, J.J.Bahain ${ }^{\mathrm{c}}$, J.M.Dolo ${ }^{\mathrm{d}}$, L.Froget ${ }^{\mathrm{a}}$, J.L.Joron ${ }^{\mathrm{e}}$, \\ H.Masaoudi ${ }^{\mathrm{c}}$, J.-L.Reyss ${ }^{\mathrm{a}}$, M.-H.Moncel ${ }^{\mathrm{c}}$
}

a) Laboratoire des Sciences du Climat et de l'Environnement, LSCE/IPSL, Laboratoire CEACNRS-UVSQ, Avenue de la Terrasse, 91198 Gif-sur-Yvette Cedex, France

b) Research School of Earth Sciences, Australian National University, ACT 0200, Australia

c) Département de Préhistoire du Muséum National d'Histoire Naturelle, UMR 5198 du CNRSUSM 204 du MNHN, 1 rue René Panhard, 75013 Paris, France

d) CEA-Saclay, Laboratoire National Henri Becquerel, 91191 Gif-sur-Yvette Cedex, France

e) Groupe des Sciences de la Terre, Laboratoire Pierre Süe, CEN, Saclay, 91191 Gif-sur-Yvette, France

\begin{abstract}
The archaeological site of Payre (France) yielded Middle Palaeolithic layers with Neanderthal remains, which are partly bracketed by two stalagmitic flowstones. To obtain a precise chronological framework for the human occupation and the faunal remains of this site, several dating methods were used: uraniumseries (U-series by alpha spectrometry and TIMS) and electron spin resonance (ESR) on stalagmitic flowstones, combined ESR/U-series on teeth and bones, and thermoluminescence (TL) on burnt flints. Most of the ages obtained for levels $\mathrm{H}$ to $\mathrm{C}$ range from $\sim 300$ to $\sim 140 \mathrm{ka}$. The age-spread obtained for the anthropic (burnt flints) and faunal remains (bones and teeth) suggests that the dated levels represent several human occupation periods, near the transition from MIS8 to MIS7 (levels G-F) and from MIS6 to MIS5 (levels D-E).
\end{abstract}

Keywords: Neanderthal, Luminescence, U-series, ESR dating, Payre, Middle Palaeolithic

\section{Introduction}

The site of Payre in Southern France is located in Jurassic and Cretaceous formations on the western bank of the Middle Rhône Valley (Fig. 1). It is part of a karstic complex opening to the south-east, $60 \mathrm{~m}$ above the Payre river, a small tributary of the Rhône (Debard, 1988). The site was first excavated in the 1960s (Combier, 1967) and quite regularly since 1990 (Moncel et al., 1993, Moncel et al., 2002; Moncel, 2003). During the last decade, the stratigraphic sequence has been the object of an interdisciplinary study, which involved geological, archaeological, palynological, palaeontological, and geochronological analyses. What is now a ca. $80 \mathrm{~m}^{2}$ open-air site at the edge of a steep slope was once a cave, before the roof collapsed. 


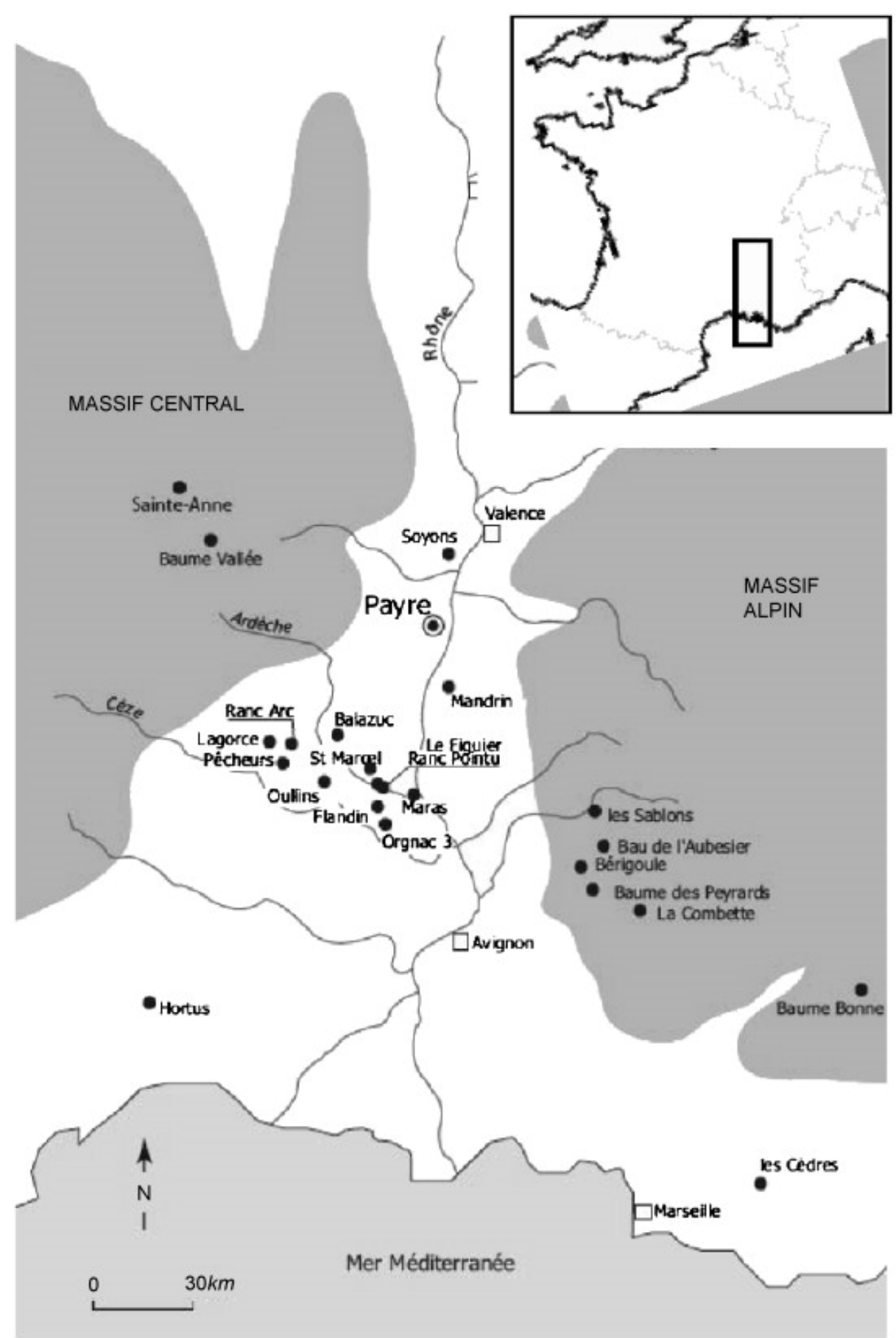

Fig. 1. Location of Payre (larger circle) and other important Middle Palaeolithic sites in the Rhône valley (Southeastern France).

Prehistoric humans repeatedly occupied the site, perhaps because of its specific location, in the vicinity of various ecosystems (Moncel et al., 2002). Middle Palaeolithic artefacts and bones were found in several layers, but the layers showing higher density of artefacts correspond to specific phases of human occupation of the site. Since Neanderthal bones were found in some layers, the dating of the site became important for a better understanding of the human occupation of the Rhône valley during the Pleistocene.

In order to set up a chronological framework for the site formation process and human occupation of Payre, several dating methods were used: uranium-series (U-series) and electron spin resonance (ESR) dating techniques were applied to geological deposits (stalagmitic flowstones) and palaeontological remains (bones and teeth), burnt flint specimens were dated by thermoluminescence (TL). 


\section{Description of the geological and archaeological sequence}

\subsection{Description of the site}

The geological study indicates that the cave, initially composed of two chambers (at first named Payre I and Payre II but now considered to be a single site) with a narrow entrance, became a rock shelter after erosion on the valley side caused a roof collapse. The excavations of large areas, up to $40 \mathrm{~m}^{2}$ in the upper layers and ca. $25 \mathrm{~m}^{2}$ in the lower layers, exposed a 5-m-thick stratigraphical sequence. Based on Fig. 2, Fig. 3, the following scenario can be proposed for the site formation processes:

- The most ancient remnants of the cave infilling are the stalagmitic floors labelled $\mathrm{H} 7$ to $\mathrm{H} 2$; they were deposited at the Western side of the cave, on the limestone substratum and under layer G. In squares L$\mathrm{M} / 13-14$, above $\mathrm{H} 2$ but not attached to this floor is found an other carbonated deposit (H1). An isolated flowstone $\mathrm{J}$ is also present in squares $\mathrm{J} 11 / \mathrm{J} 12$, under layer $\mathrm{G}$, but its exact stratigraphic location is difficult to ascertain as its connection with the $\mathrm{H} 7$ to $\mathrm{H} 2$ floors and with the archaeological layers is not apparent.

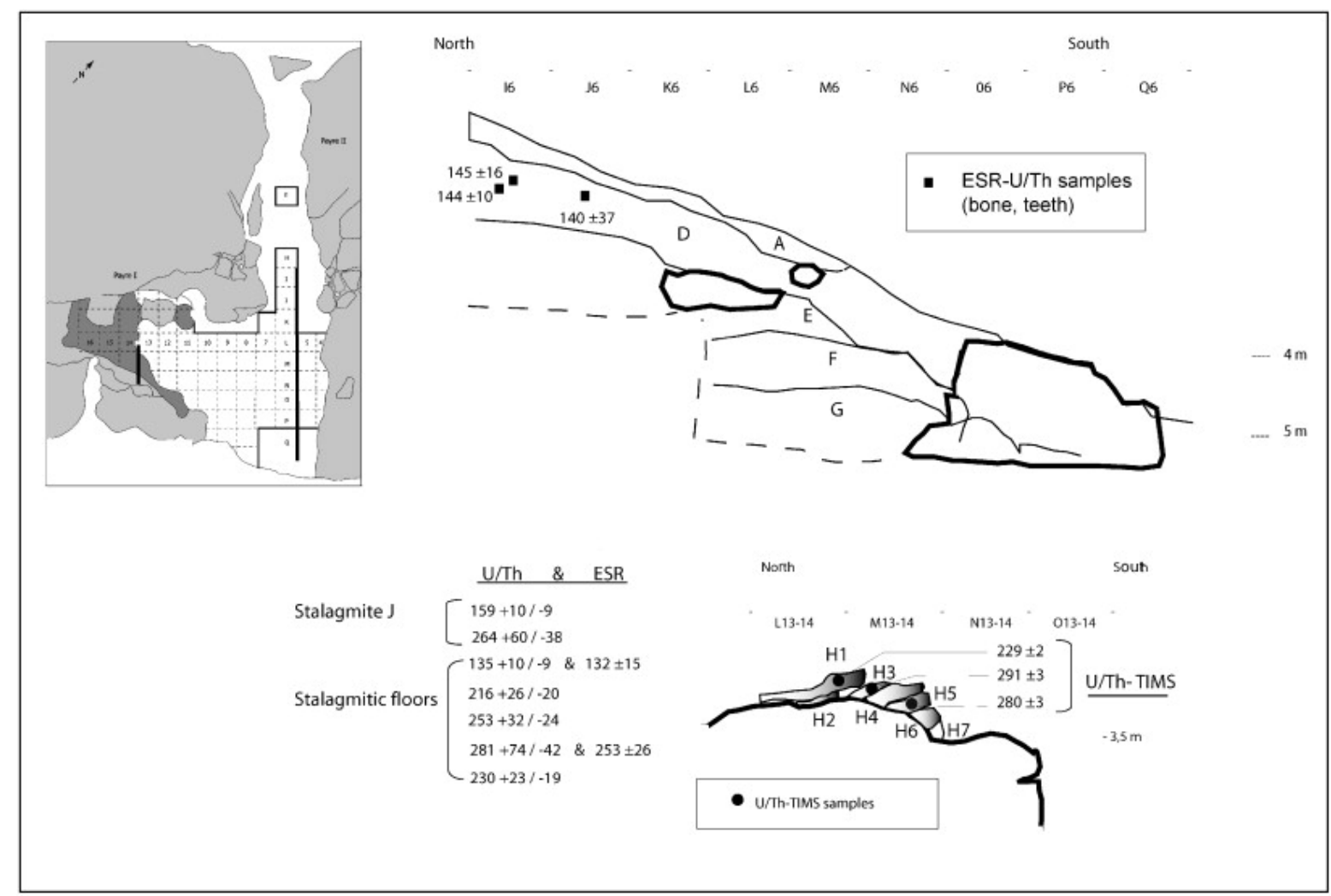

Fig. 2. Site plan with two longitudinal sections showing the location of samples used for U-series and ESR/U-series and TL datings and the age-estimates obtained. Black thick lines show the limit of the limestone rock substratum (bedrock). In the central part of the site the brescification of layer G prevented excavation and the bottom of this layer was not reached. The limits of the excavations in layer $\mathrm{G}$ are shown by dashed line. Grey patches represent stalagmitic floors. 


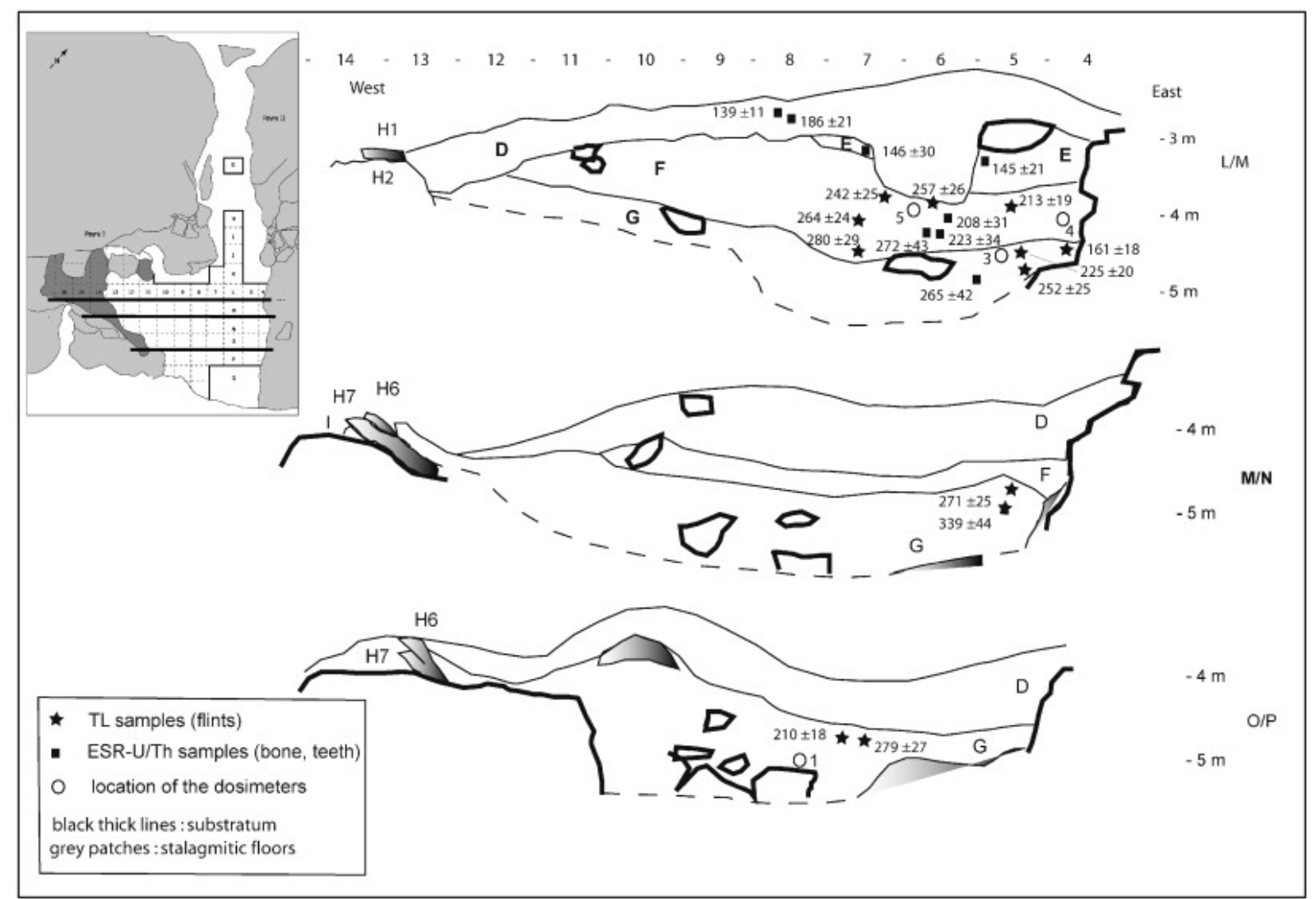

Fig. 3. Site plan with three transversal sections showing the location of samples used for the ESR/Useries and TL datings and the age-estimates obtained. Black thick lines show the limit of the limestone rock substratum (bedrock). The limits of the excavations in layer $\mathrm{G}$ are shown by dashed line. Grey patches represent stalagmitic floors.

The clastic sediment consists of the following layers:

- The overlying layer G, composed of orange clays with numerous pebbles and blocks, yielded an evidence of two main human occupation phases, which lie on the stalagmitic floors in the Eastern part of the site and directly on the substratum in the centre of the site. The contact between layer $\mathrm{G}$ and the substratum was not reached everywhere, because the high brescification of layer $G$ prevented excavations. The anthropic deposits are spread over the entire excavated surface. The top part of the sediments is eroded and also partially bresciated. This layer yielded most of the human remains, eight teeth and a fragment of a left parietal bone, within a small area. These remains belong to three or four Neanderthal individuals, from both children and adults (Moncel and Condemi, 1996, Moncel and Condemi, 1997).

- Layer F corresponds to seven cyclic deposits of grey sediment and beds of rubble and clay. It also contains four human occupation layers alternating with numerous palaeontological ones, corresponding mainly to the use of the cave by bears.

-Layer E contains large blocks of limestone from the cave roof, which had collapsed enlarging the cave entrance; the protected surface became even more reduced.

-Layers C and D (50-70 cm thick) contain brown clastic sediments which cover most of the terrace. They yielded the remains of the final human occupations, which were within sheltered area.

-Layers B and A at the top of the sequence are composed of sediments from the active karst but they do not contain any archaeological remains. 
In summary, the stratigraphic sequence is discontinuous with gaps between sedimentation layers and erosional phases, which are probably linked to the ceiling collapse.

\subsection{Palaeoenvironnemental analysis}

\subsubsection{Palynological data}

So far, no pollen has been found in layer $G$ but layer $F$ yielded a few specimens indicating a Mediterranean-type open-forest environment (Kalai et al., 2001). The pollen found in the overlying layers corresponds to a semi-open landscape, with Mediterranean influence and suggests a warming trend from layer E to D.

\subsubsection{Mammals}

Archaeozoological studies indicate that Cervus elaphus ssp., Bos primigenius and Equus cf mosbachensis are the most numerous in the entire sequence, followed by Dicerorhinus hemitoechus and Elephas. The deposits also yielded less abundant remains of some other mammals such as Stephanorinus kirchbergensis, Bison sp., Capreolus capreolus ssp., Megaloceros sp., Capra ibex, Hemitragus sp., Rupicapra sp., Sus scrofa ssp., Canis lupus ssp., Vulpes vulpes, Panthera, Panthera pardus, Crocuta crocutassp., Meles meles, Martes martes, Castor fiber, Lepus sp. Remains of Ursus spelaeus and Ursus arctos are also abundant (for instance, bears represent up to $50 \%$ of the faunal remains of layer F). These remains do not show evidence of interaction with humans and consequently one can infer that the cave was most likely used as an animal den when it was not occupied by the people. The same can be said of the carnivores (hyenas, foxes, wolves).

All these animal species belong to various ecosystems that prevailed around the site (plateau, cliff, Payre and Rhône valleys). The type of mammals found suggests a forest environment in the valleys, associated with open landscape around the cave (El Hazzazi, 1998; Desclaux, in Moncel et al., 2002).

\subsubsection{Micro-mammals}

So far the entire sequence has yielded 23 micro-mammal species. Pliomys lenki and Microtus brecciensis (Iberomys) were found in layers G and D. These species belong to the Middle Pleistocene but extend in the south of France to the beginning of the Upper Pleistocene. Four species found in the upper parts of layer D (P. lenki, M. brecciensis, Arvicola terrestris and Arvicola sapidus) point to the end of the Middle Pleistocene or the beginning of the Upper Pleistocene (El Hazzazi, 1998; Desclaux, in Moncel et al., 2002).

The species associations give evidence of two environments: an open landscape under a cold and dry climate during the deposition of layers $\mathrm{G}$ and $\mathrm{F}$, which can be attributed either to the end of the Middle Pleistocene or the beginning of the Upper Pleistocene, and an open landscape under a cold and wet climate during the deposition of the upper layer D.

\subsection{Human occupations: seasonal settlements}

The main archaeological layers G, F and D, contain lithic industries attributed to the Middle Palaeolithic period. They show no technological evolution with time, even though they display great technological and typological diversity (Moncel, 2003). Most artefacts were made of flint from a Cretaceous plateau located $10-15 \mathrm{~km}$ to the south, but basalt, limestone and quartz from the Payre river at the foot of the site as well as quartzite from the nearby Rhône river were also used for tool making. Core reduction by the "discoid method" produced large and thick flakes. The method is mainly unifacial, practiced on flint flakes or nodules. The artefacts are less retouched (10-15\%), mostly as side-scrapers and points; in some layers the points account for more than $50 \%$ of the flaked tools. The tool kit is limited in scope. It is 
completed by two large bifacial flint tools (scrapers and handaxes), which were discovered in layer G whereas quartzite, basalt, and limestone large tools (handaxes, large side-scrapers, pebble-tools) were found throughout the sequence. These large tools made of stone collected in situ were worked outside the site, while most of the flint artefacts were produced within the site.

Among the mammal species found in layers D, F, and G, Cervids, Bovids and Equids are the main species with anthropic marks, associated to rhinoceros and elephants. Archaeozoological studies indicate that the first three species were hunted by humans, while rhinoceros and elephants were probably scavenged by humans and carnivores (Lamarque and Patou-Mathis, in Moncel et al., 2002). Through the fauna remains, evidence of seasonal settlements with domestic activities is visible within each layer (large breakage of the bones, narrow butchery marks, evidence of fire with a small ashes area).

\subsubsection{Conclusion on the archaeological and palaeoenvironmental approach}

Because of their fragmentary nature, micro-mammal and palynological data yield partial information on the palaeoenvironment and they do not allow us to correlate the Payre sequence with the global marine palaeoclimatic record. Neither do the characteristics of the lithic assemblages allow the placement of the archaeological sequence within a precise period of the Middle Palaeolithic, which lasts for over $250 \mathrm{ka}$ (from ca. MIS9 to the MIS3). Consequently, several dating techniques were used to set up a chronological framework for the site formation processes and human occupation of Payre.

\section{Geochronological studies}

The dating techniques were used at the Département de Préhistoire du Muséum National d'Histoire Naturelle (MNHN) and the Laboratoire des Sciences du Climat et de l'Environnement (LSCE): U-series and ESR methods were applied to the stalagmitic deposits, TL method was used to date burnt flint specimens, which are abundant in layers $\mathrm{G}$ and F. Combined ESR/U-series method was also applied to several bones and two teeth.

\subsection{U-series and ESR dating of stalagmitic formations}

Initially, the U-series method (Ivanovich and Harmon, 1992) was applied to stalagmitic flowstones (Masaoudi, 1995). Samples PC94-01 to 05 were collected from the stalagmitic floors in squares M15/M16, deposited at the bottom of the sequence, whereas samples PC94-06 and 07 were taken from the isolated flowstone $\mathrm{J}$ (squares $\mathrm{J} 11 / \mathrm{J} 12$ ). The radioisotopic data deduced from $\alpha$-spectrometric measurements are listed in Table 1. The age estimates fall within a large time interval ranging from MIS8 to MIS6 or MIS5 (Bassinot et al., 1994): from 281+74/-42 to 135+10/-9 ka for samples from M15/M16 and from 264+60/-38 to 159+10/-9 ka for the isolated flowstone. Two of these samples (PC94-01 and PC94-04) also dated by ESR (Table 2) gave results consistent with those obtained by the U-series method. 
Table 1. Radioisotopic data and U-series ages from $\alpha$-spectrometric measurements on samples from the isolated stalagmite $\mathrm{J}$ (sampled in squares $\mathrm{J} 11 / \mathrm{J} 12$ ) and from the stalagmitic floors collected in squares M15/M16 (from Masaoudi, 1995)

\begin{tabular}{|lllrlll|}
\hline \multicolumn{1}{|c}{ Samples } & $\boldsymbol{z}(\mathbf{c m})$ & $\mathbf{U}(\mathbf{p p m})$ & ${ }^{234} \mathbf{U} /{ }^{238} \mathbf{U}$ & ${ }^{230} \mathbf{T h} /{ }^{232} \mathbf{T h}$ & ${ }^{230} \mathbf{T h} /{ }^{234} \mathbf{U}$ & U-series age (ka) \\
Stalagmite $J$ & & & & & \\
PC94-06 & 312 & 0.17 & $1.138 \pm 0.019$ & $>100$ & $0.788 \pm 0.019$ & $159+10 /-9$ \\
PC94-07 & 330 & 0.18 & $1.098 \pm 0.018$ & 11 & $0.935 \pm 0.037$ & $264+60 /-38$ \\
Stalagmitic floors & & & & & \\
PC94-01 & 310 & 0.10 & $1.080 \pm 0.025$ & $>100$ & $0.703 \pm 0.022$ & $135+10 /-9$ \\
PC94-02 & 315 & 0.20 & $1.058 \pm 0.024$ & $>100$ & $0.876 \pm 0.025$ & $216+26 /-20$ \\
PC94-03 & 324 & 0.15 & $1.082 \pm 0.022$ & $>100$ & $0.922 \pm 0.022$ & $253+32 /-24$ \\
PC94-04 & 339 & 0.18 & $1.042 \pm 0.023$ & 13 & $0.936 \pm 0.032$ & $281+74 /-42$ \\
PC94-05 & 354 & 0.84 & $1.109 \pm 0.016$ & 8 & $0.902 \pm 0.022$ & $230+23 /-19$ \\
\hline
\end{tabular}

The error on the uranium content is ca. $5 \%$.

Table 2. ESR results obtained by Masaoudi (1995) for 2 samples coming from the stalagmitic floors (sampled in squares M15/M16)

\begin{tabular}{|lllll|}
\hline \multicolumn{1}{|c}{ Samples } & $\mathbf{U}(\mathbf{p p m})$ & \multicolumn{1}{c|}{$\boldsymbol{D}_{\mathrm{E}}(\mathbf{G y})$} & \multicolumn{1}{c|}{ Dose-rate $(\boldsymbol{\mu} \mathbf{G y} / \mathbf{a})$} & \multicolumn{1}{c|}{ ESR age (ka) } \\
\multicolumn{2}{l}{ Stalagmitic floors } & & & \\
PC94-01 & 0.10 & $47.8 \pm 2.5$ & $362 \pm 36$ & $132 \pm 15$ \\
PC94-04 & 0.18 & $87.7 \pm 6.5$ & $346 \pm 34$ & $253 \pm 26$ \\
\hline
\end{tabular}

$D_{\mathrm{E}}$ : equivalent dose deduced from ESR measurements of the $g=2.0007$ signal. Dose-rate: mean annual dose estimated by taking into account disequilibrium in the U-series and the environmental (gamma+cosmic) contribution. A k-value (alpha efficiency) of 0.05 was used for the dose-rate calculation (Lyons and Brennan, 1991). The error on the uranium content is ca. 5\%.

As the large size of the samples (several grams) and their possible contamination by uranium and thorium from detritical origin could be partly responsible for the spread of the age estimates based on alpha spectrometric measurements, we tried to refine the chronology of the flowstone deposits by using the thermal ionization mass spectrometry (TIMS) U-series method (Edwards et al., 1986/87) on samples of ca. $1 \mathrm{~g}$, at the LSCE: three additional samples (depth below datum between 304 and $387 \mathrm{~cm}$, Fig. 2, Fig. 3) were collected from the bottom to the top of the stalagmitic floors in $\mathrm{H} 5, \mathrm{H} 3$ and $\mathrm{H} 1$, respectively (Table 3). 
Table 3. TIMS activity ratios and age estimates for the Payre'stalagmitic floors sampled in squares L$\mathrm{M} / 13-14$

\begin{tabular}{|c|c|c|c|c|c|c|}
\hline $\begin{array}{l}\text { Sample (depth, } \\
\text { z, cm) }\end{array}$ & $\mathbf{U}(\mathbf{p p m})$ & ${ }^{230} \mathrm{Th} /{ }^{238} \mathrm{Th}$ & $\begin{array}{l}{ }^{234} \mathrm{Th} /{ }^{238} \mathrm{Th} \\
\text { (measured) }\end{array}$ & $\begin{array}{c}{ }^{234} \mathbf{T h} /{ }^{238} \mathbf{T h} \\
\text { (initial) }\end{array}$ & ${ }^{230} \mathrm{Th} / 232 \mathrm{Th}$ & $\begin{array}{l}\text { TIMS age } \\
\text { (ka) }\end{array}$ \\
\hline \multicolumn{7}{|l|}{ Stalagmitic floors } \\
\hline $\mathrm{H} 1(z=285-305)$ & $0.15680 \pm 0.00004$ & $0.937 \pm 0.002$ & $1.053 \pm 0.001$ & $1.101 \pm 0.002$ & $32.4 \pm 0.1$ & $229 \pm 2$ \\
\hline $\begin{array}{l}\text { PL H3 }(z=300- \\
310)\end{array}$ & $0.14180 \pm 0.00003$ & $0.991 \pm 0.002$ & $1.050 \pm 0.001$ & $1.113 \pm 0.003$ & $42.0 \pm 0.1$ & $291 \pm 3$ \\
\hline $\begin{array}{l}\text { PL H5a }(z=325- \\
340)\end{array}$ & $0.16201 \pm 0.00003$ & $0.982 \pm 0.002$ & $1.048 \pm 0.001$ & $1.107 \pm 0.002$ & $26.0 \pm 0.1$ & $280 \pm 3$ \\
\hline
\end{tabular}

The analytical procedures follow Cabioch and Ayliffe (2001). 1 $\sigma$ errors are calculated by error propagation. Decay constants used in the age calculations are: $\lambda^{230} \mathrm{Th}=9.1954 \times 10^{-6} \pm 7.19 \times 10^{-8}$ and $\lambda^{234} \mathrm{U}=2.8349 \times 10^{-6} \pm 5.7 \times 10^{-9}$. The ${ }^{234} \mathrm{U} /{ }^{238} \mathrm{U}$ and ${ }^{230} \mathrm{Th} /{ }^{232} \mathrm{Th}$ activity ratios of each sample were normalised on the HU-1 standard which was assumed to be in secular equilibrium. This procedure, originally advocated by Ludwig et al. (1992), automatically corrects the data for slight machine biases and minimizes any errors introduced during spike calibration.

The U-series age-estimates are $280 \pm 3 \mathrm{ka}(\mathrm{H} 5), 291 \pm 3 \mathrm{ka}(\mathrm{H} 3)$ and $229 \pm 2 \mathrm{ka}(\mathrm{H} 1)$, indicating that the crystallization processes took place during several periods: for $\mathrm{H} 5$ and $\mathrm{H} 3$ during MIS8 and for $\mathrm{H} 1$ during MIS7. The TIMS measurements confirm the oldest $\alpha$-spectrometric results and, thanks to the high resolution of this technique, allow the chronology of the formation process to be refined. It is interesting to note that the TIMS analyses, contrarily to alpha spectrometric measurements, do not yield any results corresponding to the end of MIS6 or the beginning of MIS5 and, consequently, one can infer that the age-estimates of 135 and 153 ka reflect recrystallization events.

These U-series results suggest that the archaeological layers G, F, and E are younger than MIS9, but they do not provide a more precise age for the deposition of these layers. In order to date directly the anthropic and palaeontological remains found in archaeological layers G, F, E and D, we turned to the dosimetric methods listed below.

\subsection{Thermoluminescence dating}

This method was used to date fragments of burnt flints from the Middle Palaeolithic layers of Payre. The upper part of layer $\mathrm{D}$ was not dated because it is only a few centimeters below the actual soil surface and hence reliable dosimetric measurements could not be obtained. Twenty samples from layers $\mathrm{F}$ and G showing signs of firing were selected. Preliminary TL measurements showed that only 12 samples were suitable for TL dating: their natural TL (NTL) and their natural plus artificial TL (NTL+ATL) glow curves showed the same profile as a function of temperature, which indicates that they had been heated at temperatures in excess of $450{ }^{\circ} \mathrm{C}$. Of these, 5 specimens came from layer $\mathrm{H}$ and 7 from layer G (Fig. 2, Fig. 3).

Each flint was treated according to the procedure described by Valladas (1992): the extracted core of each specimen was crushed, sieved and the 100-160 $\mu \mathrm{m}$ grain size washed with hydrochloric acid. The palaeodose or equivalent dose $\left(D_{\mathrm{E}}\right)$ values were determined by the additive-dose technique (Mercier et al., 1995), using a ${ }^{137} \mathrm{Cs}$ gamma-ray source delivering a dose-rate of $1.48 \mathrm{~Gy} / \mathrm{min}$ (Valladas, 1978). TL measurements were done with an automatic apparatus (Valladas et al., 1994) at a heating rate of $5{ }^{\circ} \mathrm{C} / \mathrm{s}$, equipped with a Thorn EMI 9635QB photomultiplier. A MTO $380 \mathrm{~nm}$ optical filter selected the UVblue component of the emission spectrum. In Fig. 4 are shown the TL glow curves (NTL and (NTL+ATL)) of a flint (PAY3) which allowed to construct the "natural" growth curve. A "regenerative" growth curve was obtained after the sample had been heated at $350^{\circ} \mathrm{C}$ for $90 \mathrm{~min}$ to erase the NTL (Mercier et al., 1992). For PAY3 and other samples, the $D_{\mathrm{E}}$ was determined by extrapolating the natural 
and regenerated TL growth curves along the dose axis using an exponential or a polynomial function. For the PAY3 sample the values of the apparent accumulated dose as a function of temperature (plateau test) are plotted on the same figure. The $D_{\mathrm{E}}$ of this sample (152 $\pm 8 \mathrm{~Gy}$ ) was obtained by integrating the $380{ }^{\circ} \mathrm{C}$ peak from 340 to $400{ }^{\circ} \mathrm{C}$, where the plateau test was satisfied (Aitken, 1985). The estimated $D_{\mathrm{E}}$ values of the 12 selected specimens ranged from 150 to 320 Gy (Table 4).

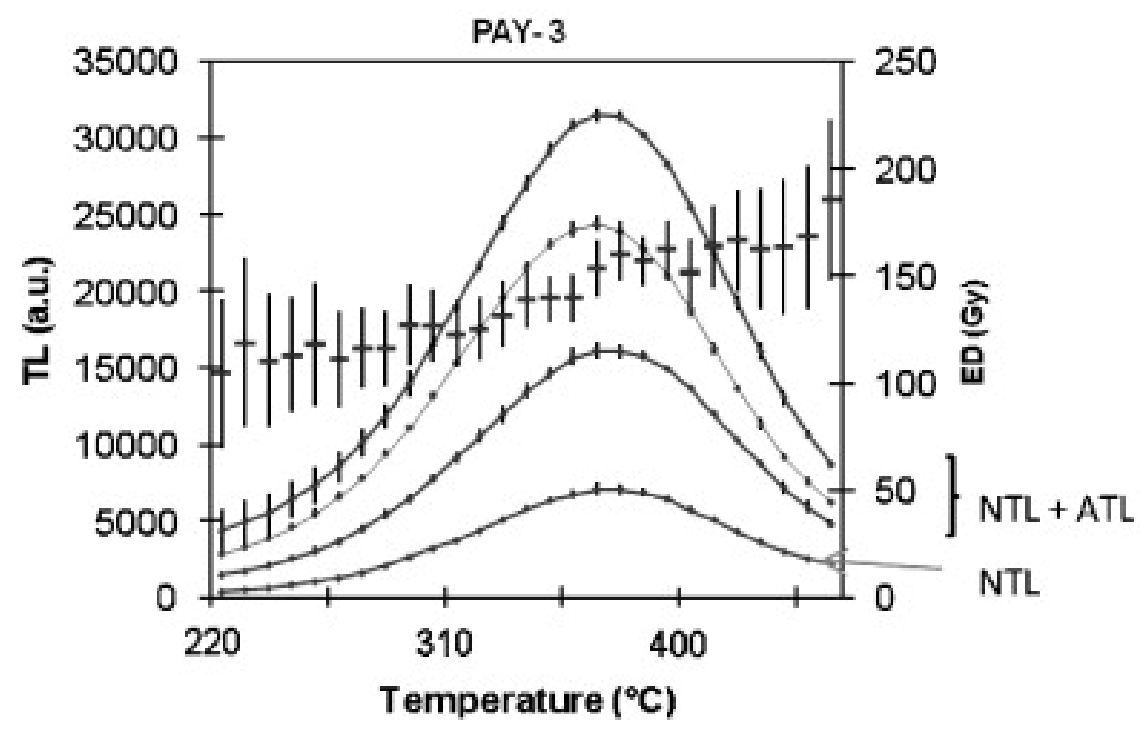

Fig. 4. Natural TL (NTL) and additive (NTL+TLA) glow curves of sample PAY3, induced by artificial gamma doses of: 19.6, 39.3 and $59.0 \mathrm{~Gy}$, respectively, together with the $D_{\mathrm{E}}$ plateau test. 
Table 4. TL data and age estimates

\begin{tabular}{|c|c|c|c|c|c|c|c|c|c|c|c|c|c|c|c|c|c|c|c|c|}
\hline \multirow{2}{*}{$\begin{array}{c}\text { Sample } \\
\text { No. }\end{array}$} & \multirow{2}{*}{$\begin{array}{l}\text { Sector } \\
\text { Layer }\end{array}$} & \multirow{2}{*}{$\begin{array}{c}\mathrm{U} \\
(\mathbf{p p m})\end{array}$} & \multirow{2}{*}{$\begin{array}{c}\text { Th } \\
\text { (ppm) }\end{array}$} & \multirow{2}{*}{$\begin{array}{c}\mathrm{K} \\
(\%)\end{array}$} & \multirow{2}{*}{$\begin{array}{c}\alpha- \\
\text { sensitivity } \\
(\mu \mathrm{Gy} / \mathrm{a} / 103 \\
\text { a) }\end{array}$} & \multicolumn{9}{|c|}{ Dose rate $(\mu \mathrm{Gy} / \mathbf{a})$} & \multirow[b]{2}{*}{ \pm} & \multirow[b]{2}{*}{$\begin{array}{c}\text { Equivalent } \\
\text { dose(Gy) }\end{array}$} & \multirow[b]{2}{*}{ \pm} & \multirow[b]{2}{*}{$\begin{array}{l}\text { Age } \\
\text { (ka) }\end{array}$} & \multicolumn{2}{|l|}{ Error } \\
\hline & & & & & & alpha & beta & Internal & \pm & Gamma & Cosmic & External & \pm & Total & & & & & statistical & total \\
\hline Pay3 & $\mathrm{F}$ & 0.52 & 0.12 & 0.02 & 22.7 & 210 & 95 & 309 & 25 & 265 & 140 & 405 & 35 & 714 & 43 & 152 & 8 & 213 & 16 & 19 \\
\hline Pay23 & $\mathrm{F}$ & 1.87 & 0.13 & 0.03 & 16.2 & 514 & 298 & 823 & 67 & 268 & 140 & 408 & 35 & 1231 & 76 & 317 & 20 & 257 & 20 & 26 \\
\hline Pay 26 & $\mathrm{~F}$ & 1.14 & 0.08 & 0.02 & 17.0 & 329 & 180 & 520 & 43 & 259 & 140 & 399 & 34 & 919 & 55 & 243 & 12 & 264 & 19 & 24 \\
\hline Pay27 & $\mathrm{F}$ & 0.4 & 0.06 & 0.01 & 10.5 & 73 & 70 & 145 & 10 & 266 & 140 & 406 & 35 & 551 & 36 & 154 & 11 & 280 & 25 & 29 \\
\hline Pay 28 & $\mathrm{~F}$ & 1.82 & 0.09 & 0.02 & 14.3 & 439 & 286 & 737 & 67 & 266 & 140 & 406 & 35 & 1143 & 75 & 277 & 14 & 242 & 20 & 25 \\
\hline Pay4 & $\mathrm{G}$ & 2.38 & 0.06 & 0.02 & 23.6 & 943 & 366 & 1333 & 119 & 197 & 132 & 329 & 25 & 1662 & 122 & 267 & 10 & 161 & 14 & 18 \\
\hline Pay5 & G & 0.65 & 0.08 & 0.02 & 17.7 & 198 & 114 & 316 & 25 & 205 & 132 & 337 & 27 & 653 & 37 & 147 & 8 & 225 & 16 & 20 \\
\hline Pay6 & $\mathrm{G}$ & 1.49 & 0.07 & 0.03 & 18.6 & 467 & 239 & 721 & 60 & 199 & 132 & 331 & 26 & 1051 & 66 & 265 & 13 & 252 & 19 & 25 \\
\hline Pay10 & G & 0.87 & 0.07 & 0.02 & 13.0 & 192 & 142 & 341 & 25 & 228 & 132 & 360 & 37 & 701 & 45 & 190 & 8 & 271 & 19 & 25 \\
\hline Pay11 & $\mathrm{G}$ & 0.41 & 0.05 & 0.01 & 13.1 & 92 & 70 & 165 & 11 & 230 & 132 & 362 & 38 & 527 & 39 & 179 & 20 & 339 & 40 & 44 \\
\hline Pay12 & G & 1.09 & 0.07 & 0.21 & 14.4 & 266 & 321 & 598 & 39 & 259 & 132 & 391 & 34 & 988 & 52 & 208 & 8 & 210 & 13 & 18 \\
\hline Pay14 & $\mathrm{G}$ & 0.98 & 0.05 & 0.01 & 15.8 & 262 & 152 & 422 & 35 & 256 & 132 & 388 & 33 & 810 & 49 & 226 & 14 & 279 & 21 & 27 \\
\hline
\end{tabular}

The combined statistical and systematic error on $\mathrm{U}$, Th and $\mathrm{K}, \pm 10 \%$, is essentially caused by uncertainties in the reference standard.

The alpha sensitivity was determined by comparing the TL- $\alpha$ and TL- $\beta$ signals induced by $\alpha$ and $\beta$ particles from $238 \mathrm{Pu}$ and $\mathrm{Y} / 90 \mathrm{Sr}$ sources, respectively (Valladas and Valladas, 1982). Depending on the sample, the error is between 8 and $16 \%$.

The internal dose-rate (and statistical error) of each flint was computed from its $\mathrm{U}$, Th and $\mathrm{K}$ contents and from the specific dose-rates given by Adamiec and Aitken (1998).

The external dose-rate (and its statistical error) was deduced from measurements taken in the field by dosimeters. The gamma contribution was corrected to take into account the absorption of the gamma rays passing through the sample. The cosmic dose-rate was estimated by assuming that the thickness of overburden (cave ceiling and sediment) was ca. 6 meters before the collapse of the cave ceiling, which occurred ca. 150 ka ago during the deposition of layer E, and only 1 meter after this collapse. The systematic error on the cosmic dose-rate has been estimated at $\pm 15 \%$. 
The $D_{\mathrm{E}}$ value (and its statistical error) was determined by extrapolating the natural and regenerated TL growth curves along the dose axis. The latter was measured after the natural powder was reheated for $1.5 \mathrm{~h}$ at $350^{\circ} \mathrm{C}$. Following Aitken's (1985) recommendations, the statistical (column 20 ) and systematic errors were calculated separately for each flint. This systematic error includes uncertainties in: (1) artificial sources calibration; (2) water content estimate at $\pm 15 \%$; (3) cosmic contribution; (4) radioisotopic contents of the standard used for the NAA. The tabulated overall error (column 21) represents the square root of the sum of the squared (systematic and statistical) errors. 
The internal dose-rate of each flint was computed from its $\mathrm{U}$, Th and $\mathrm{K}$ contents measured by neutron activation at the Pierre Süe Laboratory, CEN, Saclay (Joron, 1974) and from the specific dose-rates given by Adamiec and Aitken (1998). The uranium and thorium contents varied from flint to flint, from 0.40 to $2.38 \mathrm{ppm}$ and from 0.01 to $0.13 \mathrm{ppm}$, respectively, and the potassium content from $0.01 \%$ to $0.21 \%$. As a result of this variability the internal dose-rates ranged from 160 to $1350 \mu \mathrm{Gy} / \mathrm{a}$ and, consequently, could account for as little as $25 \%$ to as much as $80 \%$ of the total annual dose. Therefore the contribution of the environmental dose-rate varied from $75 \%$ to $20 \%$.

As the available archaeological sections around the excavated area were small and sparse, only four dosimeters (Fig. 3) could be inserted in layers F (squares L7 and M4) and G (squares O8 and L5) to measure the gamma dose-rate emitted by the radioisotopes present in the sediment and the current cosmic contribution. This last parameter was estimated to be between 140 and $132 \mu \mathrm{Gy} / \mathrm{a}$, by taking into account the present thickness of sediments above the dated layers and by assuming a $6 \mathrm{~m}$ thickness before the collapse of the roof. The gamma dose-rates reached 216 and $275 \mu \mathrm{Gy} / \mathrm{a}$ in layer $\mathrm{G}$ and were slightly higher in layer F (between 262 and $300 \mu \mathrm{Gy} / \mathrm{a}$ ) but are typical of calcareous environments. Moreover, the scatter of these values can be explained by the variable relative proportion of calcareous cobbles mixed with the terra rossa, which constitutes the sedimentological infill. Considering this information, the gamma dose-rate received by a sample was estimated from the dose recorded by the nearest dosimeters. An uncertainty of $\pm 13 \%$ which represents the standard deviation associated with the mean dose-rate value of $263 \pm 35 \mu \mathrm{Gy} / \mathrm{a}$ was used in the age calculations.

\subsubsection{Results and discussion}

The ages obtained for the 12 samples from layers $\mathrm{F}$ and $\mathrm{G}$ range from 160 to $340 \mathrm{ka}$ (Table 4, Fig. 3). For layer F, the five results are statistically compatible (Chi-square test satisfied) and cluster between $213 \pm 19$ and $280 \pm 29 \mathrm{ka}$ with an arithmetic mean of $251 \pm 25 \mathrm{ka}$. A larger spread is observed for the seven samples from the underlying layer $\mathrm{G}$, whose ages range from $161 \pm 18$ to $339 \pm 44 \mathrm{ka}$, with five falling in the 210-280 ka age interval. This large dispersion may be due to an incorrect evaluation of the external dose-rate, especially in the case of samples with low radioisotopic contents, such as PAY11 (339 $\pm 44 \mathrm{ka})$, for which the gamma contribution reaches $44 \%$ of the total dose-rate. Thus, if the presence of a clay pocket at the burial spot of this sample had raised the gamma-external dose-rate by as much as $75 \%$ above the estimated value used in the age calculation (403 instead of $230 \mu \mathrm{Gy} / \mathrm{a}$ ), the recalculated age would have been ca. $255 \mathrm{ka}$, indistinguishable from the other results obtained for this layer. The fact that the surface of layer $\mathrm{G}$ is eroded and partially bresciated could also explain some dose-rate variations. Unfortunately, these points cannot be confirmed as the excavators have removed the archaeological layers at this place. Of course, one wonders if PAY11 is not really older than the other samples, which would raise the possibility that the site was visited before the archaeological layer $\mathrm{G}$ was deposited.

If we now look at PAY4, it is also unlikely that a bad estimate of the external dose-rate could explain such a recent age $(161 \pm 18 \mathrm{ka})$, as this component contributes no more than $20 \%$ of the total dose-rate: for this sample to be $200 \mathrm{ka}$ old, the external dose-rate would have to be zero, something obviously impossible. However, it should be noted that the internal and especially the alpha dose-rate of this sample is very high $(943 \mu \mathrm{Gy} / \mathrm{a})$ due to both its high uranium and alpha sensitivity values. The model used to calculate the alpha dose-rate assuming an homogeneous distribution of both the radioisotopes and the TL emission could therefore not be well suited to this particular sample and yields an overestimate of the alpha dose-rate, and consequently would produce an under-estimated age. However, one cannot exclude the possibility that PAY4 was derived by intrusion from the overlying layer D (whose age could be close to $159+10 /-9$ ka according to the U-series method); note that layer D is full of roots which may have pushed things underneath.

If these two extreme results (PAY11 and PAY4) are excluded, the arithmetic mean age of layer G is $247 \pm 29 \mathrm{ka}$. This result is statistically indistinguishable from the mean age obtained for the overlying layer F (251 $25 \mathrm{ka})$, which suggests that these layers were deposited by the end of MIS8 (301-242 ka) and at the beginning of MIS7 (242-186 ka). The precision of the TL results is not good enough to specifically attribute the deposition of these sediments to one of these two climatic periods. 


\subsection{Combined ESR/U-series dating method}

The ESR and U-series methods are both dependent on the uranium uptake by buried fossil teeth and bones. Several models have been proposed to describe the uranium accumulation, for example, the early uptake (EU) and linear uptake (LU) models (see details in Grün, 1989; Ikeya, 1993; Rink, 1997), but the ESR method by itself does not allow one to determine this parameter. In order to circumvent this difficulty we applied an approach coupling the U-series and ESR dating methods: combining them permits to model the history of uranium uptake in a sample, which can then be characterized by a single parameter, $p$ (Grün et al., 1988; Grün and McDermott, 1994; Falguères et al., 1997).

\subsubsection{Samples and methodology}

Layer E provided only two rhinoceros teeth, which contained enamel and dentine for dating. In addition, nine fragments of large mammal bones (one from layer G, two from $\mathrm{E}$ and three from F and D, see Fig. 3) were also analysed (Moncel et al., 1993; Masaoudi, 1995; Masaoudi et al., 1997), even though such samples are known not to be reliable for dating (Grün and Schwarcz, 1987). The different tissues of the well-preserved tooth samples were separated mechanically and the outer surface of the enamel of the bones was removed using an electric drill to eliminate the material exposed to external alpha radiation. To apply the additive-dose method, nine aliquots were irradiated using a calibrated ${ }^{60} \mathrm{Co}$ gamma-ray source with doses of 50, 100, 200, 300, 400, 800, 1500, 3000, and $6000 \mathrm{~Gy}$. The ESR measurements were performed on an EMX Bruker ESR spectrometer (X-band, $9.82 \mathrm{GHz}$ ). The following parameters (10 $\mathrm{mW}$ microwave power, $0.1 \mathrm{mT}$ modulation amplitude, room temperature) were used and the $g=2.0018$ hydroxyapatite signal intensities were recorded. Each ESR measurement was repeated three times for each dose. The equivalent dose $\left(D_{\mathrm{E}}\right)$ was then determined by fitting an exponential model through the experimental points (see details in Yokoyama et al., 1985).

U-series analyses using $\alpha$-spectrometry were made on the different palaeontological tissues at the MNHN, according to the standard protocols described by Bischoff et al. (1988).

\subsubsection{Results and discussion}

The experimental data and the combined ESR/U-Th age estimates deduced are given in Table 5 and Fig.3. 
Table 5. Combined ESR/U-series data

\begin{tabular}{|c|c|c|c|c|c|c|c|c|c|c|c|c|}
\hline \multirow[t]{2}{*}{ Layer } & \multirow[t]{2}{*}{ Samples } & \multirow[t]{2}{*}{ U (ppm) } & \multirow[t]{2}{*}{${ }^{234} \mathbf{U} /{ }^{238} \mathbf{U}$} & \multirow[t]{2}{*}{${ }^{230} \mathbf{T h} /{ }^{234} \mathbf{U}$} & \multirow[t]{2}{*}{${ }^{222} \mathbf{R n} /{ }^{230} \mathbf{T h}$} & \multicolumn{2}{|c|}{ Thickness $(\mu \mathrm{m})$} & \multirow[t]{2}{*}{$D_{\mathrm{E}}(\mathrm{Gy})$} & \multicolumn{2}{|c|}{ Dose rate $(\mu \mathrm{Gy} / \mathbf{a})$} & \multirow[t]{2}{*}{$p$} & \multirow{2}{*}{$\begin{array}{c}\text { ESR/U- } \\
\text { series Ages } \\
\text { (ka) }\end{array}$} \\
\hline & & & & & & Initial & $\begin{array}{l}\text { Removed } \\
\text { on each } \\
\text { side }\end{array}$ & & Internal & External & & \\
\hline $\mathrm{D}$ & I6 182 & $41.62 \pm 0.50$ & $1.141 \pm 0.016$ & $0.611 \pm 0.013$ & 0.236 & 5900 & 425 & $353 \pm 34$ & $1934 \pm 638$ & $580 \pm 116$ & $-0.71 \pm 0.27$ & $140+40 /-34$ \\
\hline $\mathrm{D}$ & L8 210 & $25.72 \pm 0.30$ & $1.263 \pm 0.024$ & $0.536 \pm 0.017$ & 0.238 & 12,650 & 425 & $374 \pm 22$ & $823 \pm 226$ & $1164 \pm 231$ & $-0.03 \pm 0.22$ & $186+45 /-33$ \\
\hline \multirow[t]{2}{*}{$\mathrm{D}$} & $\begin{array}{l}\text { Tooth 3: } \\
\text { Enamel }\end{array}$ & $0.11 \pm 0.02$ & $1.055 \pm 0.081$ & $0.534 \pm 0.067$ & 0.303 & 2000 & 100 & $138 \pm 6$ & $40 \pm 11$ & $912 \pm 172$ & $-0.42 \pm 0.38$ & $145+33 /-23$ \\
\hline & Dentine & $15.90 \pm 0.24$ & $1.072 \pm 0.018$ & $0.235 \pm 0.007$ & 0.442 & - & - & - & - & - & $0.00 \pm 0.77$ & - \\
\hline \multirow[t]{2}{*}{$\mathrm{D}$} & $\begin{array}{l}\text { Tooth 4: } \\
\text { Enamel }\end{array}$ & $1.30 \pm 0.02$ & $1.185 \pm 0.038$ & $0.522 \pm 0.027$ & 0.334 & 2000 & 100 & $166 \pm 6$ & $245 \pm 52$ & $912 \pm 172$ & $-0.37 \pm 0.28$ & $144+31 /-22$ \\
\hline & Dentine & $24.43 \pm 0.25$ & $1.154 \pm 0.016$ & $0.523 \pm 0.012$ & 1.000 & - & - & - & - & - & $-0.37 \pm 0.25$ & - \\
\hline $\mathrm{E}$ & K6 8 & $59.33 \pm 0.60$ & $1.080 \pm 0.011$ & $0.289 \pm 0.006$ & 0.287 & 6750 & 425 & $223 \pm 27$ & $950 \pm 294$ & $572 \pm 112$ & $1.55 \pm 0.76$ & $145+37 /-27$ \\
\hline $\mathrm{E}$ & L7 230 & $29.75 \pm 0.35$ & $1.222 \pm 0.032$ & $0.769 \pm 0.026$ & 0.315 & 3375 & 425 & $335 \pm 28$ & $1685 \pm 408$ & $586 \pm 113$ & $-0.90 \pm 0.15$ & $146+34 /-26$ \\
\hline $\mathrm{F}$ & L6 30 & $69.01 \pm 1.01$ & $1.084 \pm 0.016$ & $0.331 \pm 0.010$ & 0.290 & 12,660 & 425 & $302 \pm 13$ & $905 \pm 297$ & $412 \pm 53$ & $2.55 \pm 0.97$ & $227+49 /-45$ \\
\hline $\mathrm{F}$ & M6 256 & $44.24 \pm 0.50$ & $1.079 \pm 0.018$ & $0.162 \pm 0.009$ & 0.279 & 4219 & 425 & $152 \pm 13$ & $213 \pm 86$ & $435 \pm 56$ & $8.94 \pm 2.97$ & $223+59 /-58$ \\
\hline $\mathrm{F}$ & M6 303 & $21.93 \pm 0.50$ & $1.113 \pm 0.015$ & $0.301 \pm 0.008$ & 0.385 & 8440 & 425 & $177 \pm 25$ & $216 \pm 77$ & $416 \pm 53$ & $4.16 \pm 1.47$ & $272+69 /-65$ \\
\hline $\mathrm{G}$ & O5 471 & $52.31 \pm 0.60$ & $1.143 \pm 0.041$ & $0.352 \pm 0.012$ & 0.387 & 11,000 & 425 & $283 \pm 20$ & $684 \pm 211$ & $374 \pm 47$ & $2.84 \pm 1.16$ & $265+59 /-54$ \\
\hline
\end{tabular}

The ESR ages were calculated using the following parameters: 
(1) a $k$-value of $0.13 \pm 0.02$ was used for the dental samples determined by Grün and Katzenberger-Apel (1994)and according to Grün and Schwarcz (2000). For the bones, the calculations were performed using the USIC hypothesis (US model with inverse correlation between U-content and ESR signal; $k=0$; Bahain et al., 1992). Hence, the internal dose corresponds only to the internal beta contribution.

(2) The water content was estimated to be $\pm 3 \mathrm{wt} \%, \pm 10 \mathrm{wt} \%$ and $\pm 15 \mathrm{wt} \%$ in the enamel, dentine and sediment, respectively, with an error of $\pm 33 \%$.

(3) The initial thickness of the enamel layers was $0.2 \mathrm{~cm}$ and a part of each side of the enamel layer was removed during the sample preparation (Masaoudi, 1995). So, the $\beta$-dose rate was calculated taking into account this fact and using "One Group" beta attenuations in the enamel (Brennan et al., 1997).

(4) All the calculations were performed using the program "Data-IPH" provided by Rainer Grün.

(5) The internal dose rate corresponds to the sum of the alpha and beta doses in the enamel, plus depending on the sample the beta dose from the dentine, or the beta dose in the bone. The effect of Rn losses in enamel, dentine and bone was determined by combining $\alpha$ - and $\gamma$-spectrometric measurements (Bahain et al., 1992).

(6) In computing the annual dose, the external dose rate values deduced from the TL dosimeters placed in situ in the G and F layers were used with all associated measurements errors (around $\pm 13 \%$ ). When these data were not available (D and E layers), the $\gamma$ dose rate (and its error) was calculated from the $\mathrm{U}$, Th and $\mathrm{K}$ contents of the sediment as proposed by Adamiec and Aiken (1998). An error of $\pm 20 \%$ was assumed on these calculated doses to take into account the heterogeneity of these two layers. 
The two teeth from layer D yielded statistically compatible ages $(145+33 /-23$ and $144+31 /-22 \mathrm{ka}$, respectively). The three bones from this layer gave more scattered results, between $139 \pm 11$ and $186+45 /-33 \mathrm{ka}$, pointing out the difficulty of using the combined ESR/U-series method for such material.

The two bones from layer E gave indistinguishable ages (145+37/-27 and 146+34/-26 ka), which are also similar to those obtained for layer D, suggesting that the deposition of these two layers was rapid and took place during MIS6 or at the beginning of MIS5.

The ages obtained for the bone specimens from layers $\mathrm{F}$ (from $272+69 /-65$ to $223+59 /-58 \mathrm{ka}$ ) and $\mathrm{G}$ $(265+59 /-54 \mathrm{ka})$, which are difficult to separate because of overlapping ranges, fall in MIS 8 and MIS7.

\section{Discussion and conclusion on the dating results}

Most of the age estimates obtained with the different dating methods are consistent with the stratigraphy and range from $\sim 339$ to $160 \mathrm{ka}$, i.e. from MIS9 to MIS6 (Fig. 5).
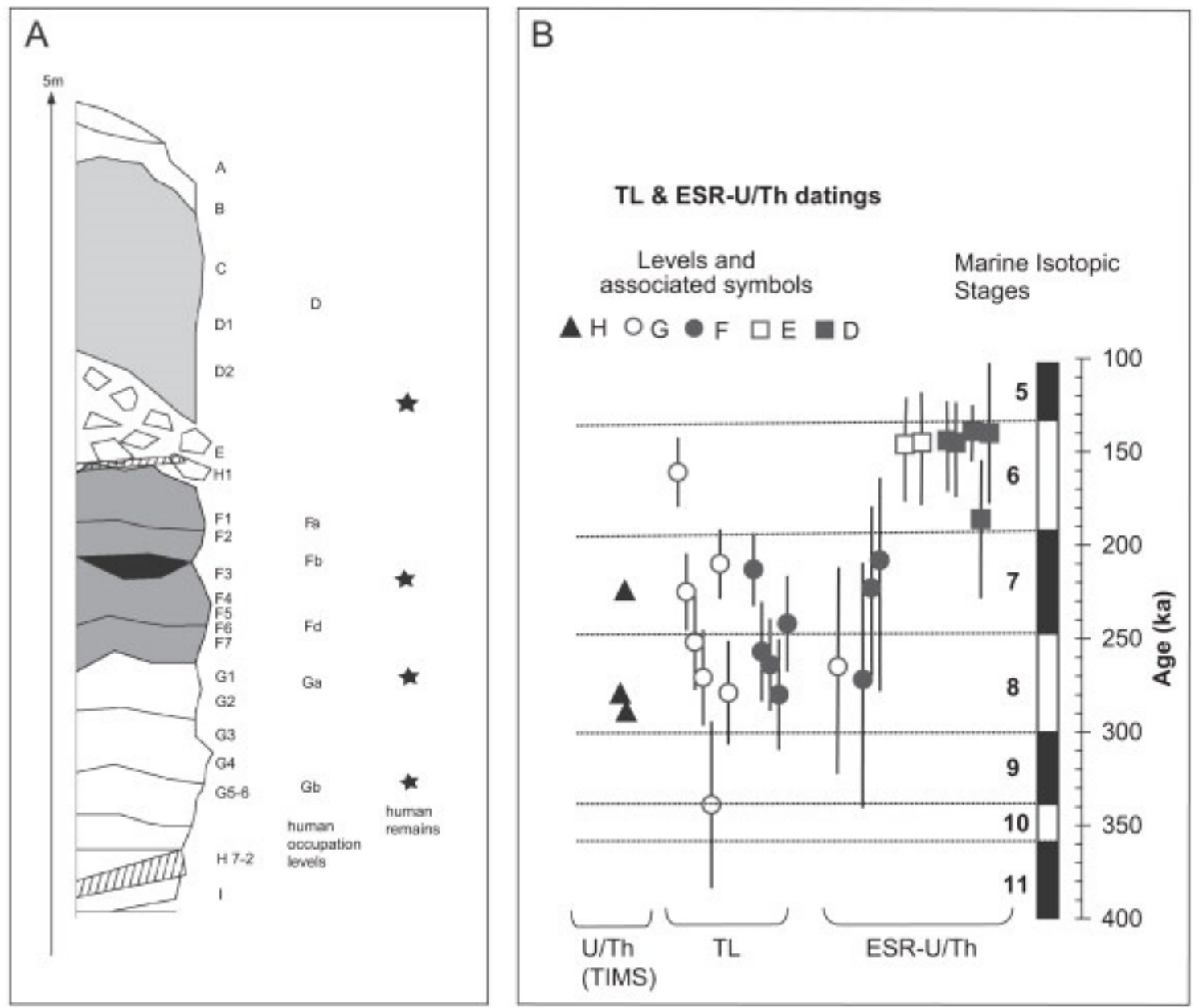

Fig. 5. Synthetic profile and age-estimates obtained on bones, teeth and burnt flints by radiometric methods (ESR/U-series and TL); the ages are plotted as a function of depth and of the isotopic marine sequence (Bassinot et al., 1994).

Thanks to its high resolution, which permits to select carefully the carbonated samples to be dated, the TIMS measurements definitively showed that the stalagmitic floors $\mathrm{H} 7$ to $\mathrm{H} 1$ crystallized mostly during MIS8 (H5 and H3 dated to 290 ka) and during MIS7 (H1: 229 $\pm 2 \mathrm{ka}$ ), as it was suggested before by the more scattered and less precise alpha spectrometric results. Most of the TL dating on burnt flints indicated that the deposition of the archaeological layers $\mathrm{G}$ and $\mathrm{F}$ took place during the same time 
interval (G: $247 \pm 29 \mathrm{ka}$ and F: $251 \pm 25 \mathrm{ka}$ ), at the end of MIS8 and the beginning of MIS7, but one sample dated at $\sim 339 \mathrm{ka}$ suggests a possible prior occupation. These average TL ages are also globally concordant with the combined ESR/uranium results obtained on bones from the same layers in spite of the inherent difficulties associated with the dating of such samples. The combined ESR/uranium yielded age estimates for layers D and E, which can be associated with the end of MIS6 or the beginning of MIS5. Actually, what are missing are samples attributable to the beginning of MIS6.

\section{Archaeological implication of the dating results}

The dating results clearly indicate that the site of Payre was occupied during the Middle Pleistocene; they also complete the chronological framework of the human settlement in the Middle Rhône Valley (Combier, 1967; Moncel, 2002, Moncel, 2003, Moncel, 2004). According to the radiometric data presented above, Payre remains chronologically between Orgnac 3 (dated to MIS9 and the beginning of MIS8), and some rare sites attributed to MIS6 and 5, for example, the bases of the sequences of Abri Moula (MIS6 and 5) and of the Abri des Pêcheurs (MIS5). Most of the other sites located along the Ardeche River, are dated to MIS4 and 3 (Debard, 1988; Defleur et al., 1990, Defleur et al., 1994; Moncel and Michel, 2000; Moncel, 2003). Thus, the archaeological data suggest that the Middle Rhône Valley was inhabited by Neanderthal people from $\sim 350$ to $~ 35 \mathrm{ka}$, perhaps due to its Southern location, while the northern part of Europe was relatively abandoned by human groups during the coldest periods (Debard, 1988; Defleur et al., 2001; Moncel, 1998, Moncel, 2003; Moncel and Michel, 2000). The mosaic landscape context could explain this quasi-continuous occupation, as well as the availability of raw material regardless of the vegetation cover.

Payre'stratigraphy brings also new information about the human behaviour inside a period, which was badly known. Orgnac 3 yielded the first evidence of Levallois knapping in this area, and one of the earliest examples of this technique in Europe (Debard and Pastre, 1988; Falgueres et al., 1988; Gauthier, 1992; El Hazzazi, 1998; Moncel, 1999; Moncel et al., 2005). The Abri des Pêcheurs, as well as Payre' sequence, attest the practice of discoid debitage on quartz during the periods of human occupations (Masaoudi et al., 1994; Prucca, 2001; Moncel et Lhomme, 2007). The Abri Moula, with its numerous human remains in level XV dated to MIS5, shows also points in common with Payre (Defleur et al., 1999, Defleur et al., 2001). All these sites suggest various kinds of Neanderthal occupations along the Rhône corridor. The sites become more numerous from MIS5-4, as is the case elsewhere in Europe, when Neanderthal features stabilized.

\section{Conclusion}

The application of the TIMS uranium-series (U-series) dating to the geological remains of Payre and the stratigraphic data shed light on the site formation process and allows do describe the evolution of the site, from a cave to an open-air site; the comparison of the dates obtained by TL on flints and by combined ESR/U-series on bones and teeth for the same layer allows to check the internal coherence of the different dates and to propose a coherent framework for Payre' human occupations. This multidisciplinary approach, which associates environmental investigations and radiometric analysis, gives new information on the human occupation of the Rhône valley during the Pleistocene. 


\section{References}

G. Adamiec, M.J. Aitken. Dose-rate conversion factors: update. Ancient TL, 16 (1998), pp. 35-70

M.J. Aitken. Thermoluminescence Dating. Academic Press, London (1985)

J.-J. Bahain, Y. Yokoyama, C. Falgueres, M.N. Sarcia. ESR dating of tooth enamel: a comparison with K-Ar dating. Quaternary Science Reviews, 11 (1992), pp. 245-250

F. Bassinot, L. Labeyrie, E. Vincent, X. Quidelleur, N. Shackleton, Y.Lancelot. The astronomical theory of climate and the age of the Brunhes-Matuyama magnetic reversal. Earth and Planetary Science Letters, 126 (1994), pp. 91-108

J.L. Bischoff, R.J. Rosenbauer, A. Tavoso, H.de. Lumley. A test of uranium-series dating of fossil tooth enamel: result from tournal cave, France. Applied geochemistry, 3 (1988), pp. 145-151

B.J. Brennan, W.J. Rink, E.L. McGuirl, H.P. Schwarcz, W.V. Prestwich. Beta doses in tooth enamel by "One Group" theory and the Rosy ESR dating software. Radiation Measurements, 27 (1997), pp. 307 314

G. Cabioch, L.K. Ayliffe. Raised coral terraces at Malakula, Vanuatu, Southwest Pacific, indicate high sea level during marine isotope stage 3. Quaternary Research, 56 (2001), pp. 357-365

Combier, J., 1967. Le Paléolithique de l'Ardèche dans Son Cadre Paléoclimatique, Mémoire 4. Bordeaux, Delmas, 462pp.

Debard, E., 1988. Le Quaternaire du Bas-Vivarais d'après l'étude des remplissages d'avens, de grottes et d'abris sous roche. Dynamique sédimentaire, paléoclimatique et chronologie, Documents Laboratoire Géologie de Lyon, 103pp.

E. Debard, J.F. Pastre. Un marqueur chronostratigraphique du Pléistocène moyen à la périphérie du Massif central: la retombée à clinopyroxène vert du Sancy dans le site acheuléen d'Orgnac 3 (BasVivarais, SE, France). CRAS, 306 (II) (1988), pp. 1515-1520

A. Defleur, H. Valladas, C. Radulescu, J. Combier, M. Arnold. Stratigraphie et datation C14 en spectrométrie de masse par accélérateur, du Moustérien récent de l'abri du Ranc de l'Arc (Ardèche, France). CRAS, 31 (II) (1990), pp. 719-724

A. Defleur, J.F. Bez, E. Cregut-Bonnoure, M. Fontugne, M. Jeannet, F.Magnin, B. Talon, M. Thinon, J. Combier. Industries, biostratigraphie, restes humains et datation du gisement moustérien de la Baume Néron (Soyons, Ardèche). CRAS, 318 (Série II) (1994), pp. 1409-1414

A. Defleur, T. White, P. Valensi, L. Slimak, E. Gregut-Bonnoure. Neanderthal Cannibalism at MoulaGuercy, Ardèche, France. Science, 286 (1999), pp. 128-131

A. Defleur, E. Cregut-Bonnoure, E. Desclaux, M. Thinon. Présentation paléo-environnementale du remplissage de la Baume Moula-Guercy à Soyons (Ardèche): implications paléoclimatiques et chronologiques. L’Anthropologie, Paris, 105 (2001), pp. 369-408

R.L. Edwards, J.H. Chen, G.J. Wasserburg. 234U-238U-230Th systematics and the precise measurement of time over past 500,000 years. Earth Planetary Science Letters, 81 (1986/87), pp. 175192 
El Hazzazi, N., 1998. Paléoenvironnement et chronologie des sites du pléistocène moyen et supérieur Orgnac 3, Payre et Abri des Pêcheurs (Ardèche, France) d'après l'étude des rongeurs. Ph.D. Thesis, Muséum National d'Histoire Naturelle, 246pp, unpublished.

C. Falguères, J.-J. Bahain, H. Saleki. U-series and ESR dating of teeth from Acheulian and Mousterian levels at La Micoque (Dordogne, France). Journal of Archaeological Sciences, 24 (1997), pp. 537-545

C. Falguères, G. Shen, Y. Yokoyama. Datation de l'aven d'Orgnac III: comparaison par les méthodes de la résonnance de spin électronique (ESR) et du déséquilibre des familles de l'Uranium. L'Anthropologie, Paris, 92 (2) (1988), pp. 727-730

Gauthier, A., 1992. Paléoenvironnement du Pléistocène moyen dans le sud de la France. Apport et limite de l'analyse pollinique de trois sites préhistoriques: Caune de l'Arago, Orgnac 3, grotte du Lazaret, Ph.D., Muséum National d'Histoire Naturelle, Paris.

R. Grün, H.P. Schwarcz. Some problems on ESR dating on bones. Ancient TL, 5 (1987), pp. 1-9

R. Grün, H. Schwarcz, J. Chadam. ESR dating of tooth enamel: coupled correction for U-uptake and Useries disequilibrium. Nuclear Tracks and Radiation Measurements, 14 (1988), pp. 237-241

R. Grün. Electron spin resonance (ESR) dating. Quaternary International, 1 (1989), pp. 65-109

R. Grün, O. Katzenberger-Apel. An alpha irradiator for ESR dating. Ancient TL, 12 (1994), pp. 35-38

R. Grün, F. McDermott. Open system modelling for U-series and ESR dating of teeth. Quaternary Science Reviews, 13 (1994), pp. 121-125

R. Grün, H.P. Schwarcz. Revised open system U-series/ESR age calculations for teeth from stratum C at the hoxnianan interglacial type locality, England. Quaternary Science Reviews, 19 (2000), pp. 1151 1154

M. Ikeya. New Applications of Electron Spin Resonance: Dating, Dosimetry and Microscopy. World Scientific, Singapore (1993) 500pp

M. Ivanovich, R.S. Harmon. Uranium-series Disequilibrium: Applications to Earth, Marine and Environmental Sciences. (second ed), Clarendon Press, Oxford (1992)

Joron, J.-L., 1974. Contribution à l'analyse des éléments en traces dans les roches et les minéraux par activation neutronique. Application à la caractérisation d'objets archéologiques. Thèse de 3ème Cycle. Université Paris-Sud.

C. Kalai, M.-H. Moncel, J. Renault-Miskovsky. Le Paléoenvironnement végétal des occupations humaines de la grotte de Payre à la fin du Pléistocène moyen et au début du Pléistocène supérieur (Ardèche, France). Trabajos de Prehistoria, Madrid, Espagne, 58 (1) (2001), pp. 143-151

K.R. Ludwig, K.R. Simmons, B.J. Szabo, I.J. Winograd, J.M. Landwehr, A.C.Riggs, R.J. Hoffman. Mass spectrometric ${ }^{230} \mathrm{Th}-{ }^{234} \mathrm{U}-{ }^{280} \mathrm{U}$ dating of the devil's hole calcite vein. Science, 258 (1992), pp. $284-$ 287

R.G. Lyons, B.J. Brennan. Alpha/gamma effectiveness ratios of calcite speleothems. Nuclear Tracks, 18 (1991), pp. 223-230

H. Masaoudi, C. Falguères, J.J. Bahain, Y. Yokohama, G. Lhomme. Datation d'ossements et de planchers stalagmitiques provenant de l'abri des Pêcheurs (Ardèche) par la méthode des déséquilibres des familles de l'Uranium (U/Th). Quaternaire, 5-2 (1994), pp. 79-83 
Masaoudi, H., 1995. Application des méthodes du déséquilibre des familles de l'uranium (230Th/234U) et de la résonance de spin électronique (ESR) à la datation des sites d'Orgnac 3, de Payre et de l'abri des Pêcheurs (Ardèche). Ph.D. Thesis, Muséum National d'Histoire Naturelle, 155pp, unpublished.

H. Masaoudi, C. Falguères, J-J. Bahain, M.-H. Moncel. Datation du site Paléolithique moyen de Payre (Ardèche): nouvelles données radiométriques (méthodes U/Th et ESR). Comptes-Rendus de l'Académie des Sciences, Paris, t324 (Série IIa) (1997), pp. 149-156

N. Mercier, H. Valladas, G. Valladas. Observations on palaeodose determination with burnt flints Ancient TL, 10 (1992), pp. 28-32

N. Mercier, H. Valladas, G. Valladas. Flint thermoluminescence dates from the CFR Laboratory at Gif: contribution to the study of the chronology of the Middle Palaeolithic. Quaternary Science Reviews (Quaternary Geochronology), 14 (1995), pp. 351-364

M.-H. Moncel, J.-J. Bahain, C. Falguères, N. El Hazzazi, C. Kalai, M.Mjahad, M. Patou-Mathis, J. Renault-Miskovsky. Le site de Payre (commune de Rompon, Ardèche). Un site Paléolithique moyen ancien dans un contexte d'abri effondré: premier bilan des études pluridisciplinaires: position chronologique. Paléoenvironnement, Paleoclimatology Quaternaire, 4 (1993), pp. 159-173

M.-H. Moncel, S. Condemi. Découverte de dents humaines dans le site Paléolithique moyen de Payre (Ardèche, France). CRAS, t322 (Série IIa) (1996), pp. 251-257

M.-H. Moncel, S. Condemi. Des restes humains dans le site Paléolithique moyen ancien de Payre (Ardèche): dents et pariétal. Nouvelles découvertes de 1996. Bulletin de la Société Préhistorique Française, 94 (2) (1997), pp. 168-171

M.-H. Moncel. Les niveaux moustériens de la grotte Saint-Marcel (Ardèche). Fouilles R.Gilles. Reconnaissance de niveaux à débitage discoïde dans la vallée du Rhône. Bulletin de la Société Préhistorique Française, 95 (2) (1998), pp. 141-171

Moncel, M.-H., 1999. Les assemblages lithiques du site Pléistocène moyen d'Orgnac 3 (Ardèche, Moyenne Vallée du Rhône, France). Contribution à la connaissance du Paléolithique moyen ancien et du comportement technique différentiel des Hommes au Paléolithique inférieur et au Paléolithique moyen, ERAUL 89, Liège.

M.-H. Moncel, V. Michel. Première tentative de datation par U-Th du site Paléolithique moyen de l'abri du Maras (Ardèche, France). Bulletin de la Société Préhistorique Française, 97 (3) (2000), pp. 371-375

Moncel, M.-H., 2002. La gestion de l'espace au travers de l'exploitation des matières premières dans la moyenne vallée du Rhône en France du stade isotopique 9 au début du stade 3: des matériaux variés et collectés au plus près par des groupes très mobiles ?. In: F. Surmely et al., Table ronde internationale: Les matières premières lithiques en Préhistoire, Aurillac, 2002, pp. 227-235.

M.-H. Moncel, E. Debard, E. Desclaux, J.-M. Dubois, F. Lamarque, M.Patou-Mathis, P. Vilette. $\quad$ Le cadre de vie des hommes du Paléolithique moyen (stades isotopiques 6 et 5) dans le site de Payre (Rompon, Ardèche): d'une grotte à un abri-sous-roche effondré. Bulletin de la Société Préhistorique Française, 99 (2) (2002), pp. 249-275

Moncel, M.-H., 2003. L'exploitation de l'espace et la mobilité des groupes humains au travers des assemblages lithiques à la fin du Pléistocène moyen et au début du Pléistocène supérieur. La moyenne vallée du Rhône entre Drôme et Ardèche », BAR Series Internationales, S1184, 179pp. 
Moncel, M.-H., 2004. Continuité et variabilité des occupations humaines à la fin du Pléistocène moyen et au début du Pléistocène supérieur (stades isotopiques 9 à 3). L'exemple de la moyenne vallée du Rhône (France). In: N.J. Conard (Ed.), Settlement Dynamics of the Middle Palaeolithic and Middle Stone Age, vol. II, Kerns Verlag Tübingen, pp. 295-317.

M.-H. Moncel, A.-M. Moigne, J. Combier. Pre-neandertal behaviour during isotopic stage 9 and the beginning of stage 8 . New data concerning fauna and lithics in the different occupation levals of orgnac 3 (Ardèche, South-East France): occupation types. Journal of Archaeological Science, 32 (2005), pp. 1283-1301

M.-H. Moncel, G. Lhomme. Les assemblages lithiques des niveaux du Paléolithique moyen de l'Abri des Pêcheurs (Ardèche, sud-est de la France). Des occupations néandertaliennes récurrentes dans un " fossé. L’Anthropologie, Paris t, t1 11 (2007), pp. 211-253

Prucca, A., 2001. Etude taphonomique d'une population de bouquetins: l'Abri des Pêcheurs (Casteljau, Ardèche), secteur 4, niveau moustérien, Master, Université de Provence Aix-Marseille I.

W.J. Rink. Electron spin resonance (ESR) dating and ESR applications in quaternary science and archaeometry. Radiation Measurements, 27 (1997), pp. 975-1025

G. Valladas. A gamma ray irradiator. PACT, 3 (1978), pp. 439-442

G. Valladas, H. Valladas. Effet de l'irradiation alpha sur des grains de quartz. A specialist seminar on thermoluminescence dating. PACT, 6 (1982), pp. 171-178

H. Valladas. Thermoluminescence dating of flint. Quaternary Science Reviews, 11 (1992), pp. 1-5

G. Valladas, N. Mercier, R. Létuvé. A simple semi-automatic TL apparatus of new design. Ancient TL, 12 (1994), pp. 39-40

Y. Yokoyama, C. Falguères, J.-P. Quaegebeur. ESR dating of quartz from quaternary sediments: first attempt. Nuclear Tracks, 10 (1985), pp. 921-928 